\title{
Size and distribution of palladium nanoparticles electrodeposited on graphite
}

\author{
I.Saldan $^{1,2}$, A.Girella $^{2}$, C.Milanese $^{2}$, E.Fratini $^{3}$, \\ O.Dobrovetska ${ }^{4}$ I.Levchuk ${ }^{4}$, O.Kuntyi ${ }^{4}$ \\ ${ }^{1}$ Department of Physical and Colloid Chemistry, Ivan Franko National \\ University of Lviv, 6 Kyryla \& Mefodia, 79005 Lviv, Ukraine \\ ${ }^{2}$ Pavia $\mathrm{H}_{2} \mathrm{Lab}$, Department of Chemistry \& CSGI, University of Pavia, \\ 16 VialeTaramelli, 27100 Pavia, Italy \\ ${ }^{3}$ Department of Chemistry \& CSGI, University of Florence, \\ 3 Via dellaLastruccia, 50019 Sesto Fiorentino, Italy \\ ${ }^{4}$ Institute of Chemistry, Lviv Polytechnic National University, \\ 12 Bandery, 79013 Lviv, Ukraine
}

Received October 20, 2017

\begin{abstract}
Morphology and particle size distribution of palladium nanoparticles obtained by pulse electrodeposition on graphite surfaces in dimethylformamide solution containing $0.01 \mathrm{M}$ $\mathrm{PdCl}_{2}$ were examined by field emission scanning electron microscopy. Chemical composition of the deposits was determined by energy dispersive X-ray spectroscopy. It was found that the average size of palladium nanoparticles increased while their density decreased with the number of pulse cycles.
\end{abstract}

Keywords: palladium, pulse electrodeposition, DMF, SEM.

Методом электронной микроскопии исследованы морфология и распределение наночастиц палладия, полученных с импульсного режима әлектроосаждения на поверхности графита в диметилформамидных растворах, содержащих $0,01 \mathrm{M} \mathrm{PdCl}_{2}$. Химический состав осадков определяли энерго-дисперсионной рентгеновской спектроскопией. Установлено, что средние размеры наночастиц палладия увеличиваются, тогда как их плотность уменьшается с количеством импульсных циклов.

Розмір та розподіл наночастинок паладію електроосаджених на графіті. I.Салдан, А.Джірелла, К.Міланезе, Е.Фратіні, О.Добровецька, І.Левчук, О.Кунтий.

Методом електронної мікроскопії досліджено морфологію і розподіл наночастинок паладію, отриманих за імпульсного режиму електроосадження на поверхні графіту в диметилформамідних розчинах,що містять $0,01 \mathrm{M} \mathrm{PdCl}_{2}$. Хімічний склад осадів визначено енерго-дисперсійною рентгенівською спектроскопією. Встановлено, що середні розміри наночастинок паладію збільшуються, тоді як їх густина зменшується 3 кількістю імпульсних циклів.

\section{Introduction}

Activity of bulk palladium might be limited in comparison with nanodispersed qand well distributed palladium nanoparticles (PdNPs), which show unexpectedly high catalytic activity in various chemical reac- tions. Additionally, the PdNPs are preferred over platinum equivalents because of their higher resistance against poisoning by different reaction species [1,2]. Detailed studies of the nanostructured palladium particles confirmed that their catalytic activity essentially depends on their size 
wherever they are introduced - on solid support, an electrode surface or even colloidal solution [3]. For mono- or bimetallic PdNPs, together with the methods of physical $[4,5]$ and chemical [6-8] syntheses, electrochemical methods [9-14] are highly reproducible and handy in practice. Electrodeposition constitutes a suitable method since it is not expensive and enables to form the nanomaterials with a wide range of sizes and shapes. Electrochemical reduction of an appropriate precursor to zero valence metal in organic aprotic electrolyte (e.g. DMSO, DMF, PC, AN [15-22]) is a reasonable approach to avoid possible secondary reactions (hydroxide formation; oxygen/hydrogen evolution) in common aqueous electrolytes. Moreover, electrodeposition in a pulse mode was found to be an effective template-free electrochemical synthetic method for the monometallic [15, 16] PdNPs.

In the present work, pulse electrochemical deposition was used to prepare PdNPs from $\mathrm{PdCl}_{2}$ salt dissolved in dimethylformamide. Morphology and chemical composition of the PdNPs were estimated by high resolution scanning electron microscopy (SEM) and energy dispersive X-ray spectroscopy (EDX). Based on the experimental results, a relationship between the mean value of the particles size and the number of pulse cycles was found.

\section{Experimental}

Organic aprotic solvent, i.e. N,N-dimethylformamide, (DMF, $99 \%$, AlfaAesar), together with tetrabutylammonium perchlorate $\left(\mathrm{Bu}_{4} \mathrm{NClO}_{4}, \geq 99.0 \%\right.$, Sigma Aldrich) as supporting electrolyte and chloride salt as metal precursors $\left(\mathrm{PdCl}_{2}\right.$, $99.9 \%$, AlfaAesar) were used in the electrochemical experiments. The prepared electrolyte has concentration of $0.01 \mathrm{M}$ in $\mathrm{PdCl}_{2}$ and $0.05 \mathrm{M}$ in $\mathrm{Bu}_{4} \mathrm{NClO}_{4}$, respectively, in the DMF solvent. Graphite rods (R8710, RINGSDORFF, SGL Carbon, GmbH) encapsulated in fluoroplastic cartridge case and gold plate $\left(S=2.2 \cdot 10^{-4} \mathrm{~m}^{2}\right)$ were used as working and counter electrodes, respectively. Silver chloride electrode manufactured as $\mathrm{Ag} / \mathrm{AgCl}$ in saturated $\mathrm{KCl}$ solution was used as a reference electrode. Before each electrochemical experiment, the graphite rods surface was mechanically polished using $3, \sim 1$ and $\sim 0.3 \mu \mathrm{m}$ microfinishing $\mathrm{SiC}$ papers followed by polishing with aluminabased suspension ( $0.3 \mu \mathrm{m}$, Metallchemie). After that, the surface of the working elec- trode was washed with distilled water and isopropanol in an ultrasonic bath and then dried under argon flow. Subsequently the three electrodes were connected to IPC-Pro 200 potentiostat and immersed into a glass cell filled with $\sim 50 \mathrm{~cm}^{3}$ of the electrolyte at $35^{\circ} \mathrm{C}$. The electrodeposition process was carried out by pulse potentiostatic method at the potential $(E)$ value of $-1.2 \mathrm{~V}$, pulse time $\left(\tau_{o n}\right)$ of $6 \mathrm{~ms}$ and pause $\left(\tau_{o f f}\right)$ of $300 \mathrm{~ms}$. These parameters were experimentally found in [15] as optimal to growth discrete nanoparticles uniformly distributed on the substrate and already used in practice for PdNPs $[15,16]$. The number of the pulse-pause repetitions $(N)$, so called "pulse cycles", varied from 3 to 50 . The obtained nanoparticles were washed sequentially in DMF and isopropanol. After that, all the samples were dried under argon flow.

Morphology of the deposits was studied by field emission scanning electron microscopy (FE-SEM). Micrographs were obtained by SIGMA high-resolution scanning electron microscope (Carl Zeiss) based on the GEMINI(r) column which features is the high brightness Schottky field emission source, beam booster, and in-lens secondary electron detector. After the electrodeposition step, the graphite rods were mounted directly on standard aluminum stubs using a bi-adhesive conductive tape. The measurements were conducted at an acceleration potential of $20 \mathrm{kV}$ and working distance of about 6-9 $\mathrm{mm}$. The chemical composition of the deposits was determined by energy-dispersive X-ray (EDX) analysis, performed by a silicon-drift detector (Oxford Instruments), directly coupled to the FE-SEM, using the optimal working distance of $8.5 \mathrm{~mm}$ and at the same value of acceleration potential.

The particle size distribution for the obtained PdNPs was modeled using the Gaussian function:

$$
f=a \cdot \exp \left[-\frac{1}{2}\left(\left(\frac{x-x_{0}}{b}\right)^{2}\right)\right],
$$

where $x_{0}$ is the mean size; $b$ is the dispersion associated to the mean value and $a$ parameter is amplitude of the Gaussian function:

$$
a=\frac{1}{b \sqrt{2 \cdot \pi}} .
$$


I.Saldan et al. / Size and distribution of ...

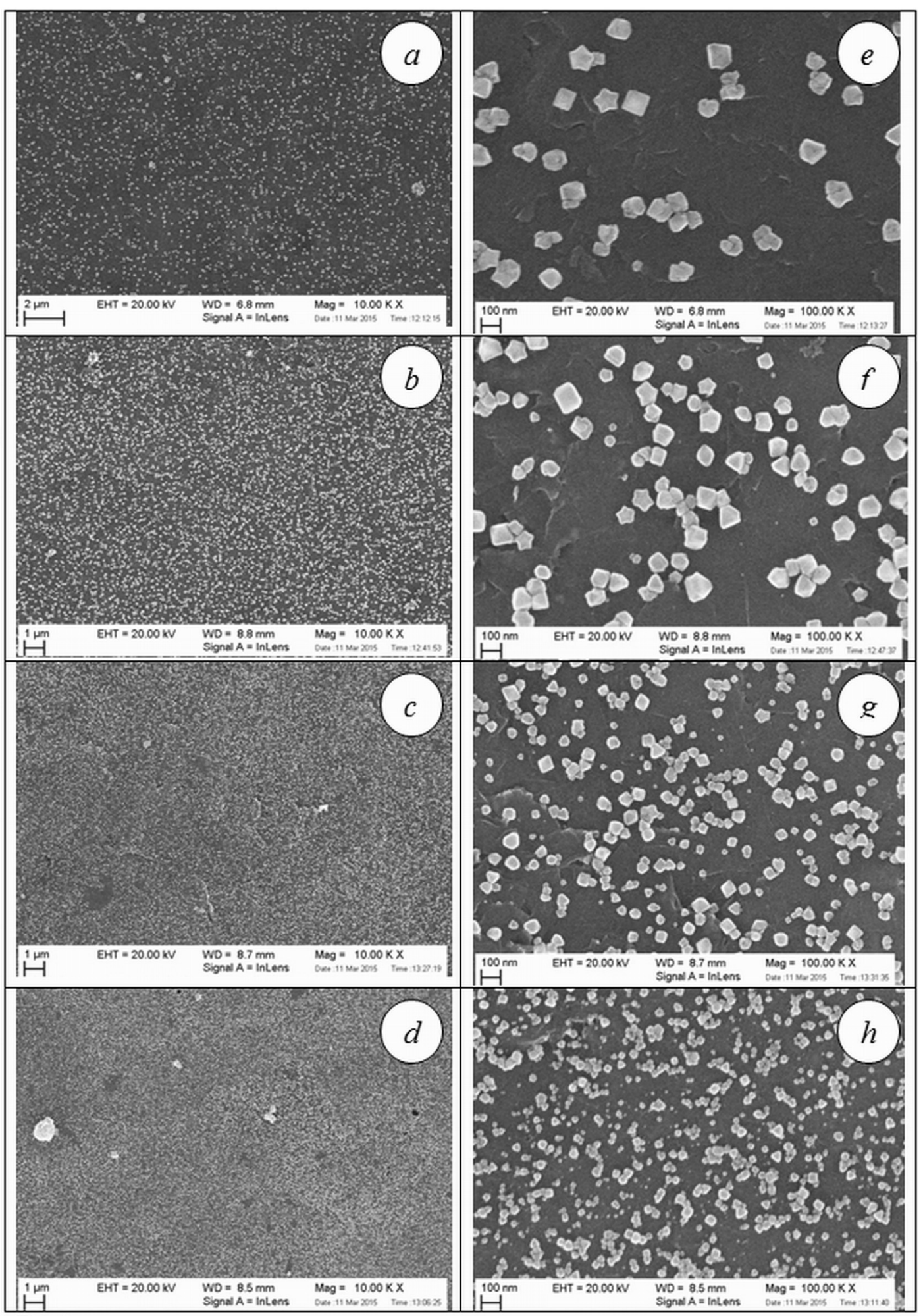

Fig. 1. SEM images for $\mathrm{Pd}$ deposition from $0.01 \mathrm{M} \mathrm{PdCl}_{2}$ solutions in DMF after $50 ; 10 ; 5$ and 3 pulse cycles at 10000 magnification (a); (b); (c) and (d) as well at 100000 magnification (e); (f); (g) and (h), correspondently. 


\section{Results and discussion}

It is well-known that electrodeposition is a multi-stage process where diffusion in electrolyte is quite often the slowest stage, i.e. the limiting step in the whole electrochemical process. Recently, it was concluded that during the pulse mode of the gold-palladium electrodeposition in dimethylsulfoxide solutions the pause corresponds to the diffusion of precursor ions (from the bulk of electrolyte to pre-electrode area) while the pulse induces nucleation and particle growth [21]. It was afterwards confirmed that surface properties of the working electrode are mainly responsible for the nucleation of nanoclusters and their subsequent growth to nano- and microdeposits. These two stages take place on the electrode surface and very often supplement each other or stay in competition. In our case, the electrochemical reduction of $\mathrm{Pd}^{2+}$ ions to metallic palladium takes place at the base of the cylindrical graphite rods. EDX analysis on the graphite rods after the electrodeposition definitely showed the Pd L emission line confirming the presence of monometallic deposits of palladium on the graphite surface. SEM images for the palladium electrodeposition after $50 ; 10 ; 5$ and 3 pulse cycles with magnification of $10 \mathrm{~K}$ and $100 \mathrm{~K}$ are shown in Fig. 1 to assess the surface morphology of the obtained PdNPs. In all cases, the uniformly distributed PdNPs were observed by SEM even though their size and density gradually changed depending on the number of pulse cycles.

The SEM images at $200 \mathrm{~K}$ magnification and the related calculated PdNPs average size distribution are shown in Fig. 2. Image analysis confirmes that the PdNPs around $18 \mathrm{~nm}$ in diameter are obtained after 3 pulse cycles, that is comparable with $29 \mathrm{~nm}$ in diameter of AuNPs [22] while a higher number of pulse cycles leads to bigger particles. In particular, in our case, after $3,5,10$ and 50 pulse cycles the mean diameter increased from $\sim 18$ to 46,89 and $101 \mathrm{~nm}$ while the calculated coverage percentage of the deposited PdNPs were 27.9, $23.4,22.0$ and $12.8 \%$, respectively. Normalized autocorrelations (Fig. 3) were done on the SEM images from Fig. 2. The small maximum (Fig. 3) at distances higher than $100 \mathrm{~nm}$ gives the typical distance between PdNPs which is around $\sim 200 \mathrm{~nm}$ in the case of 50 pulse cycles and $\sim 400 \mathrm{~nm}$ for both the cases of 10 and 5 pulse cycles. Distance between the particles is not really defined in the case of 3 pulse cycles.
Additionally, it was observed that the density of particles decreased with the number of the applied pulse cycles (Figs. 1,2). Experimental results confirm the hypothesis that after three pulse cycles the electrodeposition process is still dominated by nucleation while the growth is limited. The deposition process on a solid is thermodynamically favored at the surface defects and on the formed metallic nanoclusters. Thus, at the beginning of the electrodeposition, the palladium nanoclusters are formed at the surface defects, that is nucleation process. When all possible defects on the surface are occupied, subsequent portion of the metallic palladium covered the prepared nanoclusters, that is particle growth process. These two processes are in a permanent competition and the particle growth is preferred over nucleation at the higher number of pulse cycles.

Using the results from Fig. 2, the dependences of particle size and particle number per surface area on the number of pulse cycles are obtained (Fig. 4). The number of the PdNPs decreases while their sizes increase with the number of the pulse cycles. It is expected that the paraboloid dependence might be found experimentally using more detailed analysis beginning from the first pulse cycle. These relationships naturally confirmed a competition between the nucleation and growth stage during the pulse period.

\section{Conclusions}

The obtained experimental results confirmed the appearance of PdNPs on graphite during the beginning of palladium electrodeposition in the pulse mode. Well distributed PdNPs with size $\leq 100 \mathrm{~nm}$ in diameter were found by the SEM observation after 3-50 pulse cycles. The paraboloid dependence of the mean value of the particle size and particle number per surface area on the number of pulse cycles was experimentally found. Since the size of the PdNPs increased while their density decreased with the number of the pulse cycles a competition between the nucleation and the growth stage was proposed. In the next experimental works, attention will be focused on the geometrical shape of the PdNPs.

Acknowledgments. The research work was financially supported by the Cariplo Italian Foundation (project number 2013-0592) and $\mathrm{X} \Phi-56 \Phi$ project of the Ministry of Education and Science of Ukraine, E.F., A.G., C.M. and I.S. acknowledge financial support 


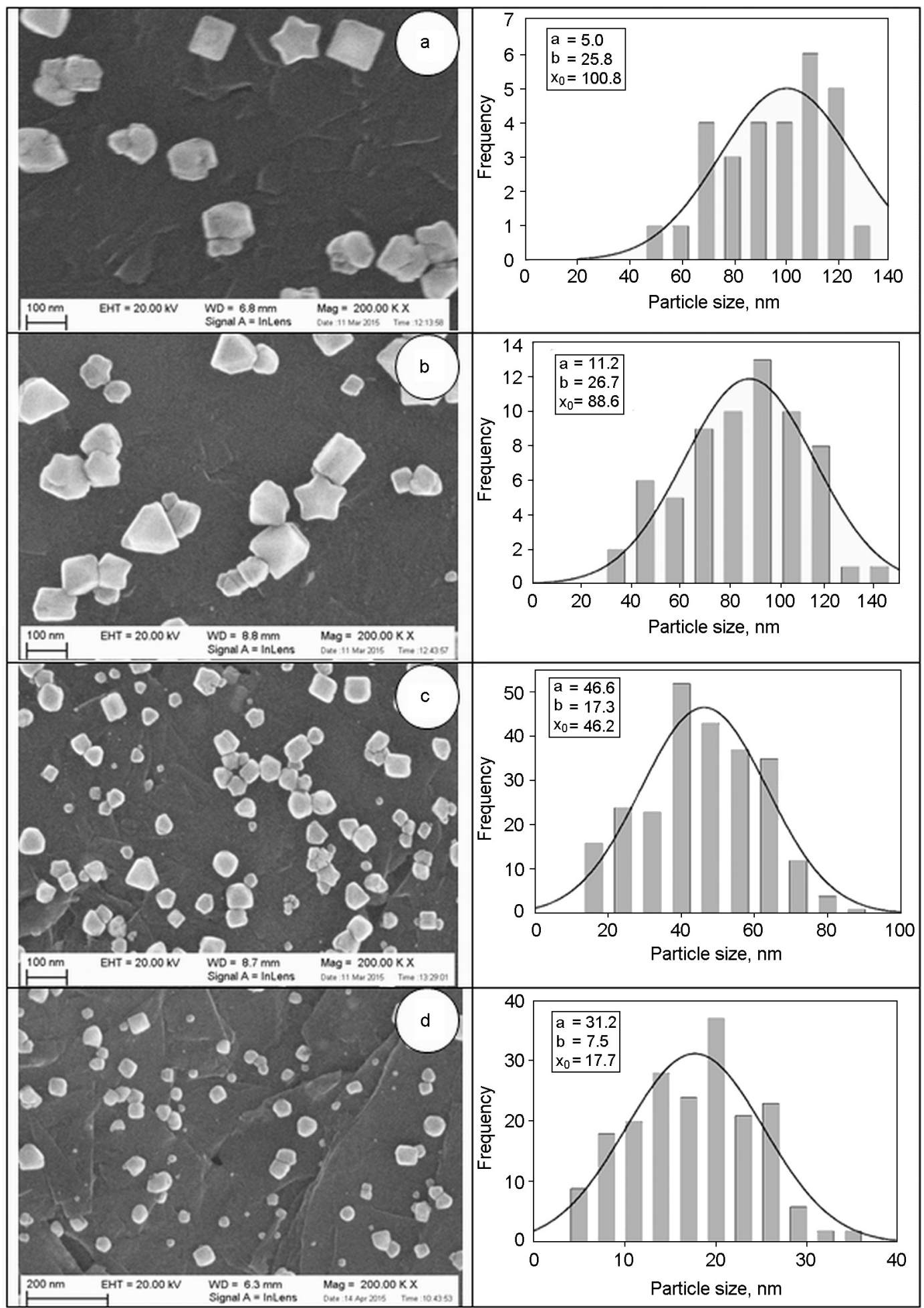

Fig. 2. SEM images for $\mathrm{Pd}$ deposition from $0.01 \mathrm{M} \mathrm{PdCl}_{2}$ solutions in DMF after $50 ; 10 ; 5$ and 3 pulse cycles at 200000 magnification (a); (b); (c) and (d), correspondently. Calculated particles distribution is shown in (e); (f); $(\mathrm{g})$ and $(\mathrm{h})$, correspondently.

from Consorzio Interuniversitario per lo Sviluppo dei Sistemi a Grande Interfase (CSGI).
Conflict of Interest: Author Chiara Milanese has received research grant from Cariplo Italian Foundation (project number 


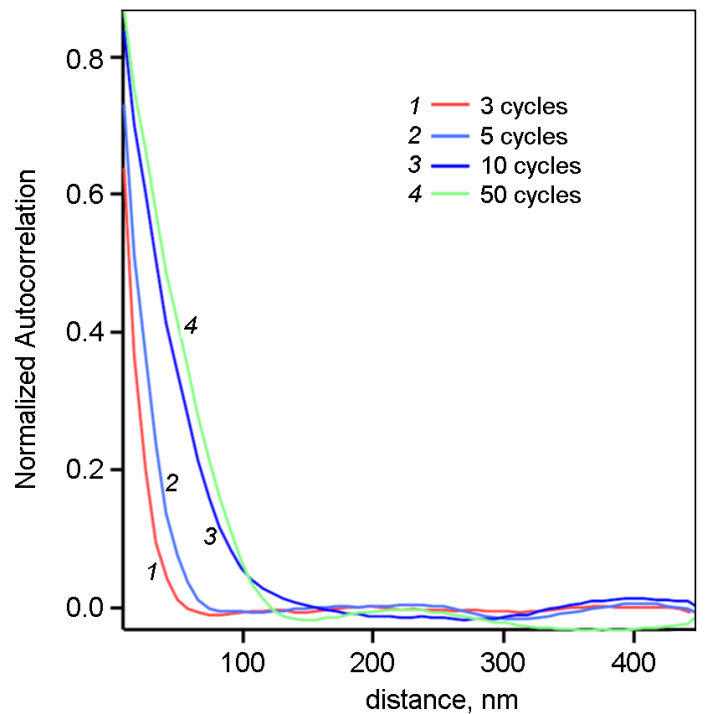

Fig. 3. Normalized autocorrelations done on the SEM images from Fig. 2. The average particle dimension can obtain via intercept on $x$-axis of tangent of the linear part at distances $<100 \mathrm{~nm}$.

2013-0592). Author Ivan Saldan is responsible executive researcher of X $\Phi-56 \Phi$ project of the Ministry of Education and Science of Ukraine.

\section{References}

1. Y.Xiong, H.Cai, B.J.Wileyet et al., J.Am. Chem.Soc., 129, 3665 (2007).

2. E.Antolini, Energy Envir.Sci., 2, 915 (2009).

3. I.Saldan, Yu.Semenyuk, I.Marchuk et al., $J$. Mater.Sci., 50, 2337 (2015).

4. K.Lee, O.Savadogo, A.Ishihara et al., J.Electrochem. Soc., 153, A20 (2006).

5. R.Ferrando, J.Jellinek, R.Johnston, Chem. Rev., 108, 843 (2008).

6. S.Y.Shen, T.S.Zhao, J.B.Xu, Electrochim. Acta, 55, 9179 (2010).

7. Z.Zhang, L.Xin, K.Sun et al., Int. J.Hydrogen Energy,36, 12686 (2011).

8. R.Singh, D.Mishra, Anindita, Int.J.Electrochem. Sci.,4, 1638 (2009).

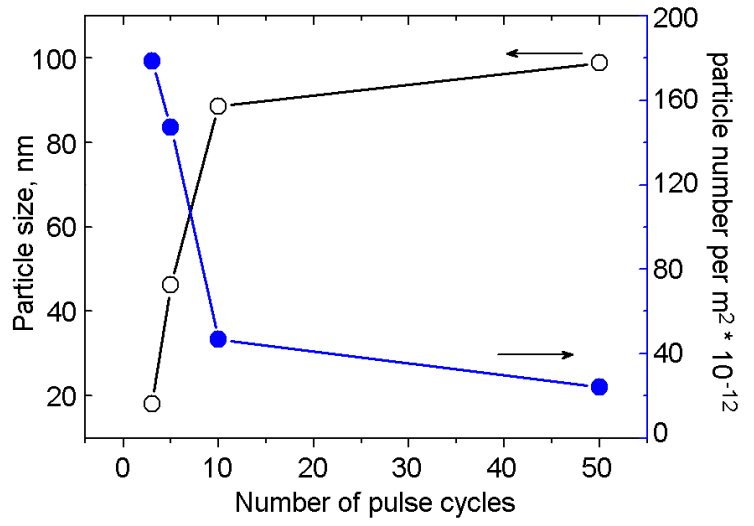

Fig. 4. Dependences of particle size and particle number per surface area on the number of pulse cycles for $\mathrm{Pd}$ deposition from $0.01 \mathrm{M}$ $\mathrm{PdCl}_{2}$ solutions in DMF.

9. T.ChikkaNagaiah, D.Schafer, W.Schuhmann et al., Anal.Chem., 85, 7897 (2013).

10. N.Abbasi, P.Shahbazi, A.Kiani, J.Mater. Chem., A 1, 9966 (2013).

11. L.-S.Jou, J.-K.Chang, T-J.Twhang et al., J. Electrochem. Soc., 156, D193 (2009).

12. C.Du, M.Chen, W.Wang et al., Electrochem. Com., 12, 843 (2010).

13. B.Tao, J.Zhang, S.Hui et al., Electrochim. Acta, 55, 5019 (2010).

14. Y.Xiao, G.Yu, J.Yuan et al., Electrochim. Acta, 51, 4218 (2006).

15. V.Pokhmurskii, O.Kuntyi, S.Kornii et al., Protec. Met. Phys. Chem. Surf., 47, 59 (2011).

16. O.Kuntyi, I.Saldan, Ye.Okhremchuket et al., Iss. Chem. Chem. Techn., 4, 306 (2011).

17. O.Kuntyi, I.Saldan, O.Bilan et al., Mater. Lett., 69, 79 (2012).

18. O.Kuntyi, I.Saldan, O.Dobrovetska et al., Phys.Chem. Mechan. Mater., 48, 511 (2012).

19. O.Kuntyi, Y.Okhremchuk, O.Bilan et al., Centr.Eur.J.Chem., 11, 514 (2013).

20. L.Sus, Y.Okhremchuk, I.Saldan et al., Mater. Lett., 139, 296 (2015).

21. O.Dobrovetska, O.Kuntyi, I.Saldan et al., Mater. Lett., 158, 317 (2015).

22. E.Fratini, A.Girella, I.Saldan et al., Mater. Lett., 161, 263 (2015). 